\title{
Identifikasi dan Uji Patogenisitas Colletotrichum spp. dari Cabai Merah (Capsicum annuum): Kasus di Kricaan, Magelang, Jawa Tengah
}

\section{(Identification and Pathogenicity Test of Colletotrichum spp. from Red Pepper (Capsicum annuum): A Case in Kricaan, Magelang, Central Java)}

\author{
Noorkomala Sari $^{1 *}$, Rina Sri Kasiamdari ${ }^{2}$ \\ (Diterima September 2019/Disetujui Maret 2021)
}

\begin{abstract}
ABSTRAK
Jenis agen penyebab penyakit perlu dikenali untuk merencanakan langkah penanganan dan pengendalian tersebarnya penyakit. Penyakit antraknosa yang menyebabkan buah busuk sering merugikan petani cabai merah (Capsicum annuum) di Indonesia karena dapat menurunkan produksi hingga $90 \%$. Fungi Colletotrichum telah banyak dilaporkan sebagai agen penyebab penyakit antraknosa pada tanaman cabai merah di Indonesia. Penelitian ini bertujuan mengidentifikasi jenis jamur patogen Colletotrichum spp. penyebab antraknosa pada buah cabai merah koleksi dari Ladang Pertanian Kricaan, Mesir, Magelang, Jawa Tengah. Metode identifikasi meliputi karakterisasi secara makroskopik dan mikroskopik dan dilanjutkan uji patogenisitas untuk mengevaluasi daya virulensi patogen. Pada penelitian ini Colletotrichum gloeosporioides dan C. acutatum teridentifikasi sebagai agen penyebab penyakit antraknosa pada buah cabai merah koleksi dari lokasi studi tersebut. Galur C. acutatum PC3 diketahui sebagai agen patogen yang paling virulen.
\end{abstract}

Kata kunci: patogen, antraknosa, cabai merah, Colletotrichum gloeosporioides, Collectricum acutatum

\section{ABSTRACT}

The investigation of the agent causing diseases is the first step to determine and control the spread of diseases. Anthracnose causing fruit rot on the red pepper in Indonesia that reduces the yield up to $90 \%$. Colletotrichum is reported as the causative fungal agent of anthracnosis on the red pepper. This study aims to determine the type of Colletotrichum spp. pathogenic fungi on the red pepper collected from Agricultural Field Kricaan, Magelang, Central Java. Methods of identification included macroscopic and microscopic characterization and followed by determining the pathogenicity of the pathogenic agent. In this study, Colletotrichum gloeosporioides and $C$. acutatum are identified as the causative agents of anthracnose in the red pepper collected from the study location. $C$. acutatum PC3 strain is identified as the most virulent pathogenic agent.

Keywords: anthracnosis, diagnosis, diseases, symptoms, pathogen

\section{PENDAHULUAN}

Tanaman cabai sebagai komoditas pertanian yang utama di Indonesia khususnya cabai merah (Capsicum annuum) banyak dipilih petani dikarenakan sifatnya yang mudah dibudidayakan, tidak bergantung pada musim, dan banyak diminati pasar baik dalam negeri dan luar negeri (Nurfalach 2010). Salah satu kendala dalam budi daya cabai merah ialah penyakit. Antraknosa atau busuk buah telah banyak dilaporkan sebagai salah satu penyakit yang sering menyerang pertanaman cabai merah. Antraknosa menyebabkan kerusakan pada buah cabai merah penurunan

1 Program Studi Agroekoteknologi, Fakultas Pertanian, Universitas Lambung Mangkurat, Jl. Brigjen H. Hasan Basri, Pangeran, Kec. Banjarmasin Utara, Kota Banjarmasin, Kalimantan Selatan 70123

2 Fakultas Biologi, Universitas Gadjah Mada, Jl. Teknika Sel., Senolowo, Sinduadi, Kec. Mlati, Kabupaten Sleman, Daerah Istimewa Yogyakarta 55281

* Penulis Korespondensi: Email: noorkomala.sari@ulm.ac.id produksi $20-90 \%$ (Wiratma et al. 1983; Semangun 2004).

Antraknosis disebabkan oleh fungi Colletotrichum spp. Colletotrichum spp. penyebab serangan antraknosis pada cabai merah telah dilaporkan, yaitu C. gloesporioides (Thind \& Jhooty 1990), C. acutatum (Istikorini 2008; Wilia 2010), dan C. capsici (Kaur et al. 2006; Rajput 2011; Sultana et al. 2012). Pada penelitian ini diisolasi dan diidentifikasi agen fungi Colletotrichum penyebab busuk buah (fruit rot) pada Ladang Pertanian Kricaan, Mesir, Magelang, Jawa Tengah.

Penelitian ini bertujuan mengidentifikasi jenis jamur patogen Colletotrichum spp. penyebab antraknosis pada buah cabai koleksi Ladang Pertanian Kricaan, Mesir, Magelang, Jawa Tengah. Jenis patogen tersebut kemudian uji patogenisitasnya untuk mengevaluasi virulensinya berdasarkan gejala yang tampak. Identifikasi jenis patogen penyebab antraknosis penting dilakukan dalam budi daya cabai merah guna menentukan langkah pencegahan dan pemutusan rantai penyakit yang lebih tepat sasaran. 


\section{METODE PENELITIAN}

\section{Isolasi Fungi Patogen}

Patogen dari bagian tanaman cabai merah keriting hibrida (F1) Lado yang terinfeksi diisolasi dari Ladang Pertanian, Kricaan, Mesir, Magelang, Jawa Tengah. Prosedur isolasi patogen diadaptasi dari Rajput (2011). Buah cabai $A, B, C$, dan $D$ yang menunjukkan gejala antraknosis masing-masing dicuci di bawah air mengalir. Bagian gejala pada buah dipotong secara aseptis dengan ukuran $0,5 \mathrm{~cm} \times 0,5 \mathrm{~cm}$. Potongan buah tersebut disterilisasi dengan $\mathrm{NaOCl} 1 \%$ selama 60 detik kemudian dibilas dengan akuades steril dan dikeringkan pada kertas saring steril. Potongan buah kering ditempelkan pada media PDA dalam cawan petri. Setiap buah (A, B, C, dan D) dipotong empat di bagian luka dan setiap potongan dikodekan dengan PA1, PA2, PA3, dan PA4; begitu juga dengan buah $\mathrm{B}$ (PB1; PB2; PB3; PB4), buah C (PC1; PC2; PC3; PC4), dan buah D (PD1; PD2; PD3; PD4). Setiap cawan diinkubasi selama tujuh hari pada suhu ruang, yaitu $27-30^{\circ} \mathrm{C}$. Koloni yang tumbuh di setiap potongan disubkultur untuk diidentifikasi jenis funginya.

\section{Identifikasi Fungi Patogen}

Proses identifikasi fungi patogen dan endofit meliputi karakter makroskopik dan mikroskopik (Watanabe 2002). Karakter makroskopik didapatkan dengan membuat kultur murni di dalam media (Potato Dextrose Agar) PDA. Karakter mikroskopik didapatkan dengan membuat preparat semipermanen. Preparat disiapkan dengan cara mengambil hifa fungi seujung ose kemudian diletakkan pada kaca objek yang sebelumnya telah ditetesi dengan gliserol; kemudian tumpukan hifa dipisahkan dengan menggunakan jarum ose dan ditetesi dengan biru trifan, selanjutnya ditutupi dengan kaca penutup dan bagian pinggirnya diolesi cat kuku. Koloni diamati di bawah mikroskop cahaya dengan perbesaran 400 kali dan dipotret dengan meng-gunakan kamera SAMSUNG GT-19500.

\section{Uji Patogenisitas}

Patogenitas diuji berdasarkan teori postulat Koch untuk memastikan bahwa isolat fungi patogen merupakan penyebab antraknosis. Uji patogenisitas dilakukan secara in vitro. Isolasi biakan fungi patogen yang telah diidentifikasi dikulturkan kembali pada media PDA. Prosedur uji patogenisitas diadaptasi dari Syukur et al. (2007). Buah dan daun dicuci dengan akuades dan disterilkan permukaannya dengan merendam pada larutan $\mathrm{NaOCI} 3 \%$ selama 60 detik kemudian dibilas dengan akuades steril. Bak plastik disiapkan dan agar terjaga kelembapannya bak dialasi tisu yang dibasahi dengan akuades steril. Setiap spesimen disayat 3 kali meggunakan pisau steril kemudian daun dan buah masing-masing diletakkan ke dalam bak. Setiap sayatan daun dan buah diinokulasikan potongan jamur ukuran $0,5 \mathrm{~cm} \times 0,5 \mathrm{~cm}$. Perubahan morfologi diamati pada daun dan buah pada hari ke-2, 4, 7, dan 9.

Skoring didasarkan pada ada atau tidaknya nekrosis pada permukaan buah dan degradasi klorofil pada daun. Apabila ditemukan gejala berupa nekrosis $\pm 1 \mathrm{~mm}$ atau daun berubah kuning dengan bercak cokelat-hitam, nilainya adalah 1 , jika tidak ada, nilainya 0 . Selanjutnya kejadian penyakit dihitung berdasarkan rumus (Syukur et al. 2007):

$$
\mathrm{DI}=(n / M) \times 100 \%
$$

Keterangan:

DI = Kejadian penyakit

$n \quad=$ Jumlah daerah yang menunjukkan gejala,

yaitu jika diameter gejala $>4 \mathrm{~mm}$

$N \quad=$ Jumlah daerah yang diinokulasikan

Daun yang diserang oleh fungi patogen akan mengalami perubahan morfologi serta anatomi sehingga untuk mengetahui infeksi patogen dapat dibuat preparat squash (Shobah 2014). Tanaman cabai merah umur tiga pekan diletakkan pada media PDA dan setiap organ daun, batang, dan akar diinokulasikan patogen. Perubahan morfologi diamati pada hari ke-7 menggunakan mikroskrop stereo.

\section{HASIL DAN PEMBAHASAN}

\section{Koleksi Buah Cabai Merah dengan Gejala Antraknosa dari Ladang Pertanian Kricaan}

Buah yang dipilih adalah buah yang menunjukkan gejala antraknosa menurut Semangun (2004) dengan ciri-ciri pada bagian permukaan buah terdapat bercak cokelat kehitaman, buah tampak berkerut, lunak, dan busuk. Berdasarkan ciri-ciri tersebut didapatkan empat buah cabai merah yang berbeda, yaitu buah A, buah B, buah $C$ dan buah $D$ (Tabel 1; Gambar 1).

Pemilihan empat buah ini didasarkan pada tingkat keparahan gejala antraknosa yang tampak. Buah $A$

Tabel 1 Deskripsi empat buah C. annuum Kultivar PM 999 yang menunjukkan gejala antraknosa koleksi dari Ladang Pertanian, Kricaan, Mesir, Magelang, Jawa Tengah

\begin{tabular}{ll}
\hline \multicolumn{1}{c}{ Buah } & \multicolumn{1}{c}{ Deskripsi } \\
\hline A & Permukaan buah berwarna merah, terdapat bercak hitam dengan garis diameter > 4 mm, luas bercak \\
& $10 \%$ \\
B & Permukaan buah berwarna merah, bercak hitam menyebar, daging buah lunak, luas bercak 45\% \\
C & Permukaan buah berwarna hitam pada bagian gejala yang menyebar, luas bercak 55\% \\
D & Permukaan buah berwarna hijau, bercak hitam menyebar hampir seluruh permukaan buah, luas bercak \\
& $90 \%$
\end{tabular}



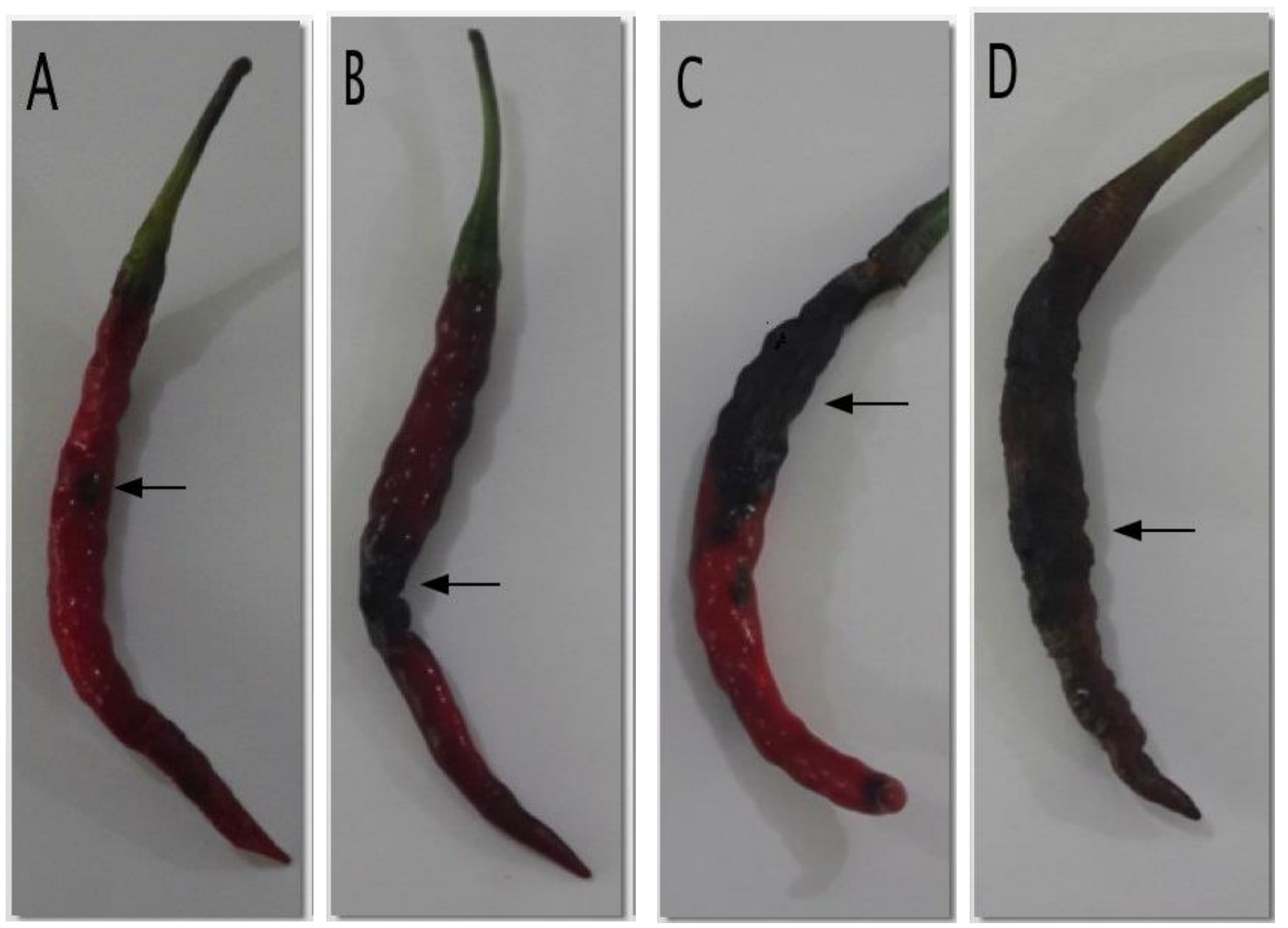

Gambar 1 Empat buah cabai merah yang menunjukkan gejala antraknosa (ditunjukkan arah panah) koleksi dari Ladang Pertanian, Kricaan, Mesir, Magelang. A: buah A, B: Buah B, C: Buah C dan D. Buah D.

menunjukkan gejala antraknosa awal, yaitu berupa luka kecil berwarna hitam dengan diameter $\pm 5 \mathrm{~mm}$ dan sedikit cekung (Tabel 1, Gambar 1A). Deskripsi ini sesuai dengan laporan Rajput (2011), bahwa gejala antraknosa diawali dengan titik gelap, sedikit cekung, dan bergaris tengah $1 \mathrm{~mm}$. Pada buah $\mathrm{B}$, gejala antraknosa ditandai dengan daerah hitam yang lebih melebar dibandingkan dengan $\mathrm{A}$, daging buah tampak lunak pada daerah luka, dan ada pengerutan daging buah pada daerah tersebut (Tabel 1, Gambar 1B). Pada buah $\mathrm{C}$, gejala semakin melebar dengan hampir $50 \%$ permukaan buah menjadi hitam, daerah hitam tersebut tampak lunak karena busuk (Tabel 1, Gambar 1C). Adapun tingkat keparahan gejala tertinggi terdapat pada buah $\mathrm{D}$, yaitu hampir keseluruhan buah menjadi busuk, warna merah cabai berubah menjadi cokelat (Tabel 1, Gambar 1D), yang oleh Semangun (2004) dideskripsikan sebagai serangan berat, seluruh buah mengering dan mengerut (keriput), warna buah menjadi kecokelatan bahkan hitam.

\section{Isolat dan Identitas Fungi dengan Gejala} Antraknosa

Diketahui ada empat isolat yang berhasil diidentifikasi sebagai Colletotrichum, yaitu isolat dengan kode PA1, PB4, PC2b dan PC3. Tiga isolat yang berhasil diidentifikasikan sebagai Fusarium sp. lalah PA3, PB1b (Fusarium oxysporum) dan PC2a ( $F$. roseum). Tujuh isolat (PA2; PB1a; PB2a; PB2b; PB3a; PB3b; dan PC4) tidak berhasil diidentifikasi (Tabel 2).

PA1, PB4, PC2b dan PC3 dapat diidentifikasi sebagai Colletotrichum dengan ciri-ciri mikroskopik, yaitu jumlah konidia yang banyak, hifa berseptat, ada/tidak adanya seta atau acervuli. Secara makroskopik koloni pada media tumbuh berwarna putih abu-abu hingga jingga (Tabel 2). Isolat PA1 diidentifikasi sebagai $C$. gloesporioides karena memiliki seta dan konidia silinder. Adapun isolat PB4, PC2b, PC3 diidentifikasi sebagai $C$. acutatum karena tidak memiliki seta dan konidia berbentuk fusiform (Gambar 2).

Acutatum termasuk spesies Colletotrichum yang memiliki jumlah seta sedikit atau sama sekali tidak memilikinya karena seta (setae) tumbuh pada kondisi tertentu (Peres et al. 2005). Hal ini sesuai dengan rujukan (Zivkovic et al. 2010b), bahwa C. acutatum memiliki ciri mikroskopik berupa hifa berseptat, hialin, konidia falcate, dan tidak memiliki skelerotia, seta, maupun aservulin. Koloni PDA bewarna abu-abu pucat, miselia aerial berwarna putih, tebal dan mengapas (cottony), miselia bercabang, berseptat dan hialin.

C. gloesporioides dan C. acutatum dilaporkan sebagai spesies penyebab penyakit antraknosa pada tanaman cabai di Indonesia (Wiratama et al. 2013). Kedua spesies ini dapat ditemukan bersama-sama dalam satu inang (one host) ataupun satu spesies 
Tabel 2 Daftar fungi yang berhasil diidentifikasi dari buah C.annuum bergejala antraknosa dari Ladang Pertanian Kricaan, Mesir, Magelang, Jawa Tengah

\begin{tabular}{|c|c|c|c|c|}
\hline $\begin{array}{l}\text { Kode } \\
\text { Isolat }\end{array}$ & $\begin{array}{l}\text { Pengamatan } \\
\text { makroskopik }\end{array}$ & $\begin{array}{c}\text { Pengamatan } \\
\text { mikroskopik }\end{array}$ & $\begin{array}{c}\text { Referensi } \\
\text { identifikasi }\end{array}$ & Hasil Identifikasi \\
\hline PA1 & $\begin{array}{l}\text { Warna koloni putih } \\
\text { dengan bintik jingga } \\
\text { pada tengah koloni; } \\
\text { permukaan } \\
\text { mengapas pinggiran } \\
\text { tidak rata (Gambar } \\
2 \mathrm{~A}, \mathrm{~B})\end{array}$ & $\begin{array}{l}\text { Bersepta; konidiamata/aservuli } \\
\text { berseta terang hingga cokelat } \\
\text { gelap; konidia uniseluler, hialin, } \\
\text { silindris (membulat pada ujung); } \\
\text { konidiofor hialin hingga gelap } \\
\text { (Gambar 2C) }\end{array}$ & $\begin{array}{l}\text { Rojas et al. 2010; } \\
\text { Kim et al. 2009; } \\
\text { Than et al. 2008a; } \\
\text { Jayasingher \& } \\
\text { Fernando 2009; } \\
\text { Weir et al. } 2012\end{array}$ & $\begin{array}{l}\text { Colletotrichum } \\
\text { gloeosporioides }\end{array}$ \\
\hline PA3 & $\begin{array}{l}\text { Warna koloni putih; } \\
\text { permukaan } \\
\text { mengapas; ada hifa } \\
\text { aerial; pinggiran rata }\end{array}$ & $\begin{array}{l}\text { Berseptat; klamidiospore bulat } \\
\text { lonjong; konidia falcate bersekat } 4\end{array}$ & Watanabe, 2002 & Fusarium roseum \\
\hline PB1b & $\begin{array}{l}\text { Warna koloni abu-abu } \\
\text { hingga hitam dengan } \\
\text { pinggiran putih; } \\
\text { permukaan } \\
\text { mengapas; pinggiran } \\
\text { rata }\end{array}$ & $\begin{array}{l}\text { Berseptat; makrokonidia falcate } \\
\text { bersekat } 4 ; \quad \text { mikrokonidia } \\
\text { subsilindris hialin }\end{array}$ & Watanabe 2002 & F. oxysporum \\
\hline PB4 & $\begin{array}{lr}\text { Warna } & \text { abu-abu } \\
\text { dengan } & \text { pinggiran } \\
\text { putih; } & \text { permukaan } \\
\text { mengapas; } & \text { pinggiran } \\
\text { tidak rata; } & \text { (Gambar } \\
\text { 2D, E) } & \end{array}$ & $\begin{array}{l}\text { Bersepta; tidak ditemukan seta; } \\
\text { konidia hialin uniseluler, fusiform, } \\
\text { aseptat, apresoria berwarna } \\
\text { terang hingga kecokelatan, } \\
\text { berjumlah sedikit (Gambar } 2 \mathrm{~F} \text { ) }\end{array}$ & $\begin{array}{l}\text { Peres et al. } 2005 \text {, } \\
\text { Than et al. } 2008 \mathrm{~b}\end{array}$ & C. acutatum 1 \\
\hline PC2a & $\begin{array}{l}\text { Warna koloni putih; } \\
\text { permukaan } \\
\text { mengapas; ada hifa } \\
\text { aerial; pinggiran rata }\end{array}$ & $\begin{array}{l}\text { Berseptat; } \\
\text { klamidiospora; konidiofor hialin, } \\
\text { pendek; konidia hialin, falcate, } \\
\text { bersekat } 4\end{array}$ & Watanabe 2002 & F. roseum \\
\hline PC2-b & $\begin{array}{lr}\text { Warna } & \text { abu-abu } \\
\text { dengan } & \text { pinggiran } \\
\text { putih; } & \text { permukaan } \\
\text { mengapas; } & \text { pinggiran } \\
\text { tidak rata } & \text { (Gambar } \\
2 \mathrm{G}, \mathrm{H} \text { ) } & \end{array}$ & $\begin{array}{l}\text { Bersepta; tidak ditemukan seta; } \\
\text { konidia hialin, fusiform, uniseluler, } \\
\text { aseptat; apresoria terang hingga } \\
\text { kecokelatan, berjumlah sedikit } \\
\text { (Gambar 2) }\end{array}$ & $\begin{array}{l}\text { Peres et al. 2005; } \\
\text { Than et al. } 2008 b\end{array}$ & C. acutatum 2 \\
\hline PC3 & $\begin{array}{lr}\text { Warna } & \text { abu-abu } \\
\text { dengan } & \text { pinggiran } \\
\text { putih; permukaan } \\
\text { mengapas; pinggiran } \\
\text { tidak rata (Gambar } 2 \mathrm{~J}, \\
\text { K) }\end{array}$ & $\begin{array}{l}\text { Bersepta; tidak ditemukan seta; } \\
\text { konidia hialin, fusiform, uniseluler, } \\
\text { aseptat; apresoria terang hingga } \\
\text { kecokelatan, berjumlah sedikit } \\
\text { (Gambar 2L) }\end{array}$ & $\begin{array}{l}\text { Peres et al. 2005; } \\
\text { Than et al. 2008b }\end{array}$ & C. acutatum 3 \\
\hline
\end{tabular}

dapat menyerang berbagai inang (multiple host) (Syukur et al. 2007).

Koloni dari C. gloesporioides dan C. acutatum memiliki warna yang beragam dari putih ke jingga hingga abu-abu kehitaman (Peres et al. 2005; Weir et al. 2012). Perbedaan yang sangat berarti dari kedua spesies ini ialah bentuk konidia, dengan kedua ujung konidia C. gloesporioides membulat (subsilindrical) (Gambar 2C), sedangkan pada $C$. acutatum minimal pada salah satu ujungnya melengkung (fusiform) (Gambar 2F; I; L) (Than et al. 2008b). C. acutatum memiliki laju pertumbuhan yang rendah dibandingkan dengan C. gloesporioides (Than et al. 2008b; Jayasinghe dan Fernando 2009). Hal ini dibuktikan dengan jarak pertumbuhan koloni pada hari ke-7, yakni C. acutatum (Gambar 2 D-K) memiliki jarak pertumbuhan koloni 3-4 $\mathrm{cm}$ dibandingkan dengan $C$. gloesporioides (Gambar 2A-B) yang mencapai pinggir cawan $(9 \mathrm{~cm})$.
Isolat PA3, PB1b dan PC2a diidentifikasi sebagai Fusarium karena makrokonidianya yang khas, yaitu berbentuk sabit (falcate) dan bersekat (1-3 sel), mikrokonidia bulat lonjong (silindris), klamidiaspora catenulate, dan konidiafor pendek (Tabel 2). Isolat PA3 dan $\mathrm{PC} 2 \mathrm{a}$ diidentifikasi sebagai $F$. roseum karena memiliki mikro dan makrokonidia, klamidiaspora soliter atau kembar (Tabel 2). PB1b diidentifikasi sebagai $F$. oxysporum berdasarkan klamidiaspora dalam rantaian 3 spora dan tinggi konidiofor lebih rendah daripada makrokonidianya (Tabel 2). Pengidentifikasian genus ini disesuaikan dengan rujukan oleh Watanabe (2002) menurut karakteristik morfologi.

\section{Patogenisitas Isolat dari Buah Cabai Merah yang bergejala Antraknosa secara in vitro}

Patogenisitas diuji secara in vitro untuk mengevaluasi tingkat patogenesitas di antara keempat Colletotrichum spp., yaitu Colletotrichum gloesporioides, C. acutatum 1, 2, dan 3 yang 

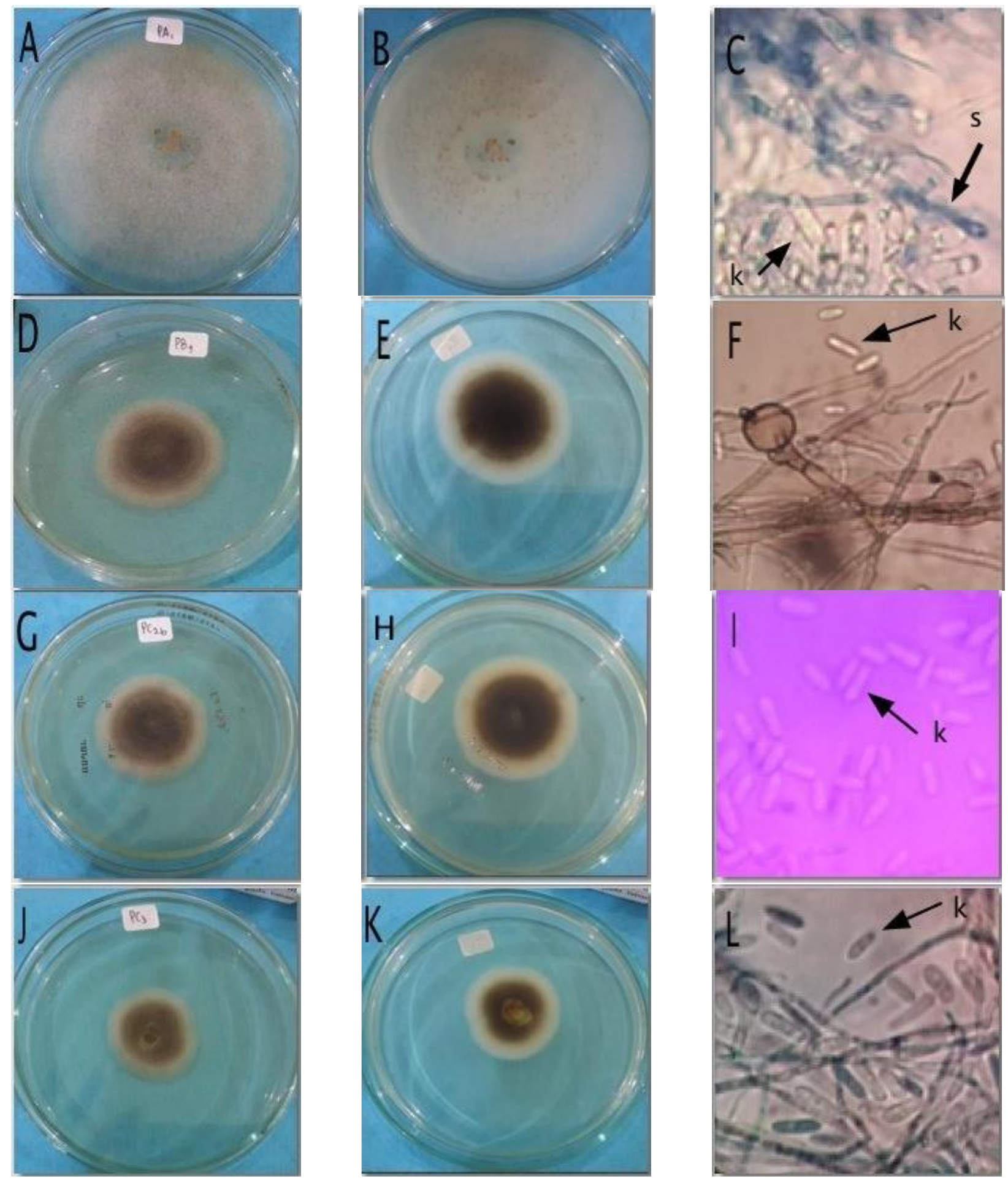

Gambar 2 Koloni tampak depan dan belakang kultur hari ke-7 dan konidia Colletotrichum spp. dari buah cabai dengan gejala antraknosa. C.gloesporioides PA1 (A-C), C.acutatum PB4 (D-F), C.acutatum PC2b (G-I), C.acutatum

menyebabkan penyakit. Pengujian secara in vitro diadaptasi dari Syukur et al. (2007) menggunakan bahan uji daun dan buah C. annuum kultivar PM 999. Berdasarkan hasil uji patogenisitas secara in vitro setelah inokulasi Colletotrichum spp., belum ada daun dan buah yang menunjukkan gejala pada hari ke-2. Gejala mulai terlihat hari ke-4 pada inokulasi $C$. acutatum 3 dan terus menunjukkan keparahan penyakit hingga hari ke-9 (Tabel 3).

Kemampuan menimbulkan penyakit oleh Colletotrichum spp. dapat diketahui dari perkembangan penyakit selama 9 hari. Hasilnya memperlihatkan bahwa $C$. acutatum 3 mampu menimbulkan penyakit yang paling parah dengan rata-rata persentase $100 \%$ pada daun dan buah pada hari ke- 9 
Tabel 3 Persen kejadian penyakit pada daun dan buah C. annuum kultivar PM 999 pada hari ke-2, 4, 7, dan 9 oleh Colletotrichum spp.

\begin{tabular}{lllllllll}
\hline \multirow{2}{*}{ Perlakuan } & \multicolumn{8}{c}{ Kejadian penyakit pada hari ke- } \\
\cline { 2 - 9 } & 2 & 4 & 7 & 9 & 2 & 4 & 7 & 9 \\
\hline Kontrol & 0 & 0 & 0 & 0 & 0 & 0 & 0 & 0 \\
C. gloesporioides & 0 & 0 & 33,3 & 33,3 & 0 & 0 & 0 & 0 \\
C. acutatum 1 & 0 & 0 & 0 & 66,67 & 0 & 0 & 0 & 0 \\
C. acutatum 2 & 0 & 0 & 33,3 & 100 & 0 & 0 & 33,3 & 33,3 \\
C. acutatum 3 & 0 & 33,3 & 100 & 100 & 0 & 0 & 66,7 & 100 \\
\hline
\end{tabular}

Keterangan: Kontrol (tanpa perlakuan), C. gloesporioides (PA1), C. acutatum 1 (PB4), C. acutatum 2 (PC2b), C. acutatum 3 (PC3)

(Tabel 3). Tingginya nilai kejadian penyakit menunjukkan kemampuan jamur tersebut dalam menimbulkan penyakit dan seberapa besar serangan yang ditimbulkan pada tanaman (Syukur et al. 2009). Semakin lama masa inokulasi, semakin tinggi nilai kejadian penyakit (Tabel 3). Hal ini mengindikasikan bahwa keganasan patogen dipengaruhi oleh waktu. Jamur membutuhkan waktu untuk germinasi spora, pertumbuhan miselium, degradasi dinding sel inang, penetrasi ke sel inang, dan penyerapan nutrisi.

Kejadian penyakit pertama kali diawali oleh $C$. acutatum 3 pada hari ke-3 (Tabel 3). Menurut Syukur et al. (2009) kejadian penyakit yang diakibatkan infeksi C. acutatum berkisar 11,25-97,5\% pada beragam genotipe C.annuum. Dalam hal ini C. acutatum 3 unggul dalam hal kecepatan kejadian penyakit dan keparahan penyakit. Diduga isolat tersebut sanggup menginfeksi lebih cepat dengan mensekresikan enzim pendegradasi dinding sel sehingga mampu menimbulkan kejadian penyakit paling cepat, yakni pada daun hari ke-4 (33,33\%), pada buah hari ke-7 $(66,67 \%)$, dan hari ke-9 (100\%) baik pada buah maupun daun. Disimpulkan bahwa nilai patogenisitas tertinggi didapatkan pada C. acutatum 3 (Tabel 3). Selain itu $C$. acutatum dilaporkan sebagai spesies paling dominan menyerang tanaman cabai merah di Indonesia (Syukur et al. 2007).

Guna mengevaluasi infeksi patogen pada jaringan tanaman, telah dibuat preparat squash untuk dilihat struktur anatominya (Gambar 3). Tanda panah pada Gambar 3D-F menunjukkan bahwa terjadi kolonisasi hifa patogen ke dalam jaringan epidermis dan vaskuler tanaman cabai merah. Pada perlakuan daun (Gambar 3D) kolonisasi $C$. acutatum telah menginfeksi hingga ke jaringan vaskuler. Hal inilah yang menyebabkan daun berwarna cokelat kekuningan akibat degradasi klorofil yang disebabkan oleh kolonisasi patogen. Adapun pada bagian batang pada perlakuan (Gambar $3 E)$, hifa menginfeksi hingga pada bagian jaringan vaskuler (xilem), hifa berwarna kecokelatan dengan membentuk apresoria. Pada akar (Gambar 3F), hifa mengkolinisasi daerah epidermis secara intraseluler.

Patogen Colletotrichum pada jaringan inang dapat menginfeksi melalui dua mekanisme, yaitu kolonisasi intraseluler/kolonisasi subkutikular intramural dan hemibiotripik intraseluler. Sebagian utama
Colletotrichum melakukan kolonisasi subkutikular intramural. Seperti yang dilaporkan oleh Perfect et al. (1999) spora C. capsicil C.gloesporioides bergerminasi membentuk apresoria menembus dinding kutikula inang, hifa jamur kemudian menyebar secara subkutikular di antara dinding sel epidermis hingga mesofil sel. Penyebaran hifa ini menyebabkan sel-sel di sekitarnya mati.

\section{KESIMPULAN}

Agen patogen penyebab antrakanosa pada cabai merah Kultivar PM 999 dari Ladang Pertanian Kricaaan, Mesir, Magelang, Jawa Tengah adalah Colletotrichum gloeosporioides, C. acutatum 1, C. acutatum 2, dan C. acutatum 3. C. acutatum 3 merupakan isolat paling virulen yang menyebabkan penyakit antraknosa berdasarkan hasil uji patogenisitas.

\section{UCAPAN TERIMA KASIH}

Penulis mengucapkan terima kasih kepada pemilik Lahan Pertanian Kricaan, Magelang, Jawa tengah yang menyediakan hasil pertaniannya sebagai objek studi pada penelitian ini.

\section{DAFTAR PUSTAKA}

Istikorini Y. 2008. Potensi Cendawan Endofit untuk mengendalikan penyakit Antraknosa pada Cabai (Capsicum annum L.). [Tesis]. Bogor (ID): Institut Pertanian Bogor.

Kaur M, Sharma OP, Sharma PN. 2006. In Vitro effect of Thricoderma Species on Colletotrichum capsisi Causing Fruit Rot of Chilli (Capsicum annum L.). Indian Phytopath. 59(2): 243-245.

Kim WG, Hong SK, Choi HW, Lee YK. 2009. Occurrence of Anthracnose on Highbush Blueberry Caused by Colletotrichum Species in Korea. Mycobiology 37(4): 310-312. https://doi.org/ 10.4489/MYCO.2009.37.4.310 

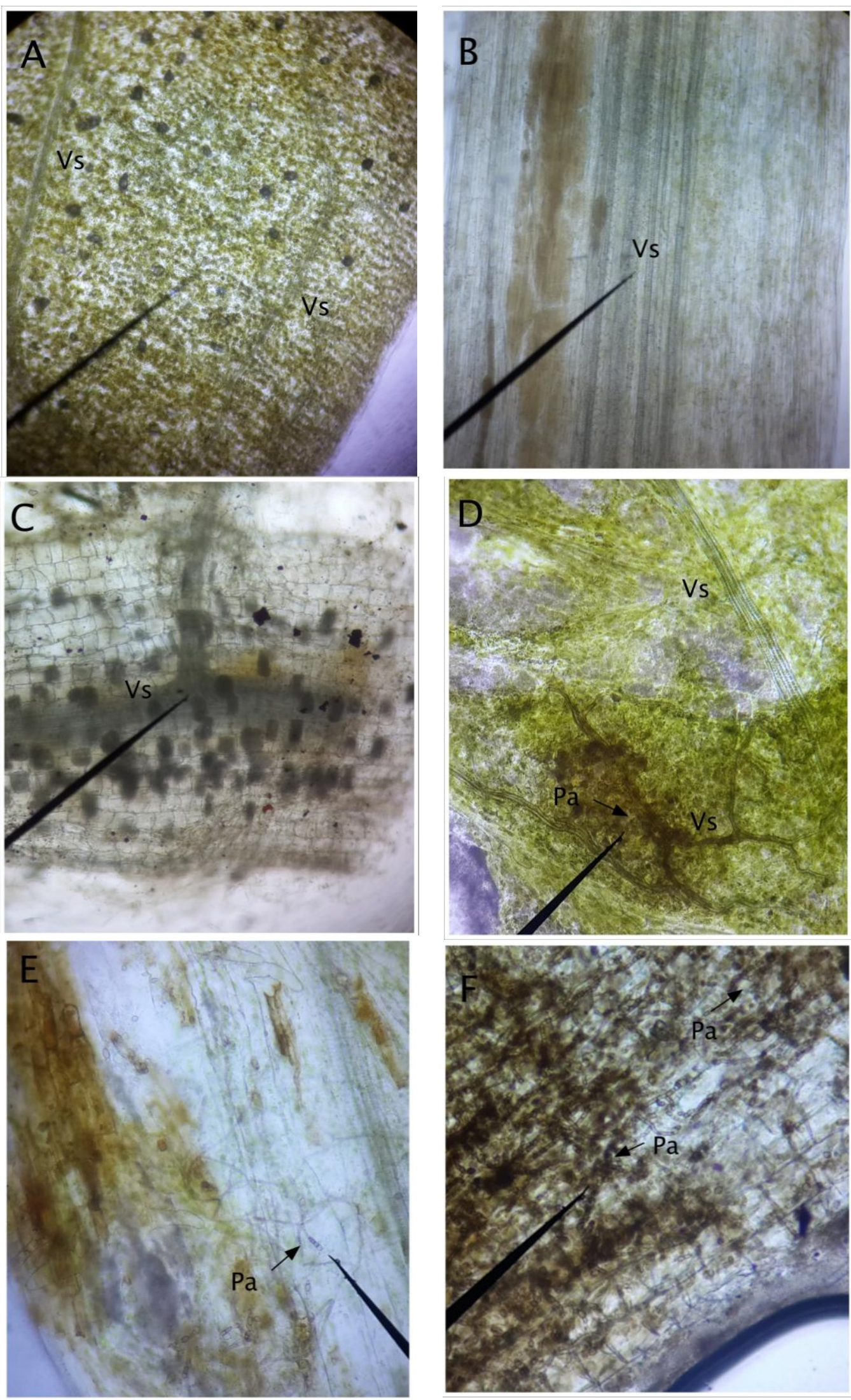

Gambar 3 Struktur anatomi tanaman cabai merah yang terinfeksi patogen $C$. acutatum pada hari ke-7. Kontrol (A-C): A: preparat epidermis daun, B: preparat membujur batang, C: preparat membujur akar. Perlakuan (D-F). D: preparat epidermis daun, E: preparat membujur batang, F: preparat membujur akar. Vs = jaringan vaskuler, $\mathrm{Pa}$ = kolonisasi hifa dan apresoria C.acutatum (ditandai dengan tanda panah). 
Nurfalach DR. 2010. Budidaya Tanaman Cabai Merah (Capsicum annum L.). [Skripsi]. Surakarta (ID): Universitas Sebelas Maret.

Rojas El, Rehner SA, Samuels GJ, Bael SAV, Herre EA, Cannon P, Chen R, Pang J, Wang R, Zhang Y, Peng Y, Sha T. 2010. Colletotrichum gloeosporioides s.l. associated with Theobroma cacao and other plants in Panama: multilocus phylogenies distinguish host-associated pathogens from asymptoomatic endophytes. Mycologia (102)6: 1318-1338

Semangun H. 2004. Penyakit-penyakit Tanaman Hortikultura di Indonesia. Yogyakarta (GB): UGM Press.

Shobah AN. 2014. Identifikasi Fusarium Penyebab Penyakit Layu Pada Tanaman Cabai (Capsicum annuum L.) dan Pengendaliannya dengan Mikoriza Vesikula Arbuskula (MVA). [Tesis]. Yogyakarta (ID): Universitas Gadjah Mada.

Sultana JL, Pervez Z, Rahman H, Islam MS. 2012. Invitro Evaluation of Different Strains Trichoderma harzianum and Chaetomium globasum as Biological Control Agents Seedling Mortality of Chilli. Bangladesh Research Publications Journal. 6: $305-310$

Syukur M, Sujiprihati S, Koswara J, Widodo. 2007. Pewarisan Ketahanan Cabai (Capsicum annuum L.) Terhadap Antraknosa yang Disebabkan Oleh Colletotrichum acutatum. Jurnal Agronomi Indonesia 35(2): 112-117.

Syukur M, Sujiprihati S, Koswara J, Widodo. 2009. Ketahanan terhadap Antraknosa yang disebabkan oleh Colletotrichum acutatum pada beberapa genotipe Cabai (Capsicum annuum L.) dan korelasinya dengan kandungan Kapsaicin dan Peroksidase. Jurnal Agronomi Indonesia. 37(3): 233-239.

Than, P.P., Prihastuti, H., Phoulivong, S., Taylor, P.W.J and Hyde, K.D. 2008a. Review: Chilli antracnose disease caused by Colletotrichum species. Journal of Zhejiaang University Science. B9(10): 764-778.
Than PP, Jeewon R, Hyde KD, Pongsupasamit S, Mongkolporn O, Taylor PWJ. 2008b. Characterization and pathogenicity of Colletotrichum spesies associated with anthracnose on chilli (Capsicum spp.) in Thailand Plant Pathology, 57(3): 562-572

Thind TS, Jhooty S. 1990. Studies on variability in two Colletotrichum species causing anthracnose and fruit rot of chillies in Punjab. Indian Phytopathology. 43: 53-58.

Peres NA, Timmer LW, Adaskaveg JE, Correll JC. 2005. Lifestyles of Colletotrichum acutatum. Plant Disease. 89(8): 784-796

Watanabe T. 2002. Pictorial Atlas of Soil and Seed Fungi (Morphologies of Cultured Fungi and Key to Species) 2nd Edition. CRC Press, Florida 33431, United State of America.

Wiratama IDMP, Sudiarta IP, Sukewijaya IM, Sumiartha K, Utama MS. 2013. Kajian Ketahanan beberapa Galur dan Varietas Cabai terhadap Serangan Antraknosa di desa Abang Songan Kecamatan Kintamani Kabupaten Bangil. E-Jurnal Agroekoteknologi Tropika. 2(2): 71-81

Wiratma DA, Murwani ER, Sastrahidayat IR. 1983. Pengaruh Komponen Cuaca Terhadap Tingkat Serangan Jamur Colletotrichum sp. Penyebab Antraknosa Pada Cabe Rawit di Laboratorium. Kongres Nasional PFI Ke VII Medan, 21-23 September 1983. Medan (ID).

Wilia W. 2010. Potensi Cendawan Endofit dan Khamir untuk Mengendalikan Penyakit Antraknosa (Colletotrichum acutatum L.) pada Tanaman Cabai. [Tesis]. Bogor (ID): Institut Pertanian Bogor.

Zivkovic S, Stojanovic S, Ivanovic Z, Trkulja N, Dolovac N, Aleksic G, Balaz J. 2010b. Morphological and Moleculer Identification of Colletotrichum acutatum from Tomato Fruit. Pesticidii Fitomedicina. (Belgrade) 25(3): 231-223. 